Tér és Társadalom 21. évf. 2007/2. 151. p.

Tér és Társadalom

XXI. évf. 2007 2: 151

\title{
BESZÁMOLÓ
}

\section{EURACADEMY OBSERVATORY - NEMZETKÖZI OKTATÁSI KUTATÁSI PROJEKT}

Az MTA RKK NYUTI egy, az Európai Unió Leonardo da Vinci Szakképzési Programja által finanszírozott kutatás, az Euracademy Observatory tagjaként az elmúlt két év során a vidéki területek képzési palettájával foglalkozott. A felnőttképzés részeként az infokommunikációs technológiákkal (IKT) támogatott, élethosszig tartó tanulás lehetőségeinek és kihasználtságának felmérésére elöször történtek erőfeszitések hazánkban. A kutatás három fỏ részbỏl állt. Elsőként az IKT által támogatott élethosszig tartó tanulással kapcsolatos politikák európai és nemzeti szintü felmérése történt meg. A második és harmadik fảzis egy-egy online kérdőíves kutatást foglalt magában. Az első felmérésben, a projektben részt vevő hét ország - Magyarország, Görögország, Németország, Finnország, Spanyolország, Lengyelország, Nagy-Britannia - rurális térségeire jellemző, képzési kínálati oldal bemutatása és elemzése volt a cél. A második felmérésben a képzéseken résztvevők tanulási igényei, a képzések munkaerö-piaci sikerességre kifejtett hatása volt a vizsgálat tárgya.

Magyarországon a nagy volumenú, államilag támogatott IT infrastruktúra kiépítések folyamata a végéhez közeledik. A lakosság érzékenyebbé tétele és az újfajta technológiák elfogadtatása napjaink legnagyobb feladata. A digitális írástudatlanság ma már nem a lehetőségek hiányából, hanem annak kihasználatlanságából fakad. Az IKT-val támogatott képzések elfogadottsága az új technológiák elfogadottságával párhuzamosan nö. Nem véletlen tehát, hogy az IKT-val támogatott képzések nagy hányada ma még magának a technológiának a használatát oktatja. A felsőoktatásban a távoktatásban kifejlesztett és használatos technikák és módszerek napjainkban szivárognak le az oktatás, többek között a felnőttképzés egyéb szintjeire.

A projektben részt vevó hét ország a nemzeti adatfelvételeket egy közös, a projekt befejeztével nyilvánosan elérhetô adatbázisban kívánja elhelyezni, hogy további kutatásokhoz és elemzésekhez nyújthasson segitséget. A kutatás zárókonferenciájára 2007. szeptember 7-8-án került sor Brüsszelben.

A projekt honlapja az alábbi honlapcímen érhetó el:

http://www.euracademy-observatory.org

Szörényiné Kukorelli Irén-Baj Gabriella 